\title{
Bekkenreservoar - sporadisk kirurgi bør sentraliseres
}

\author{
Bekkenreservoarkirurgi er et behandlingsalternativ til permanent ileostomi. Prosedyren er kompleks, \\ og faren for havari og komplikasjoner er høy. Det burde være innlysende at en slik prosedyre ikke bør \\ gjøres sporadisk ved kirurgiske avdelinger, slik situasjonen er i dag.
}

De siste 30 år har man kunnet tilby pasienter med behov for å få fjernet tykk- og endetarm et alternativ til permanent utlagt tynntarm (ileostomi) - bekkenreservoaret. Ulcerøs kolitt og familiær adenomatøs polypose er de meste aktuelle diagnosene for prosedyren. Et tynntarmsegment omdannes til et reservoar (pouch) som sys ned på endetarmsåpningen (ileoanal anastomose). Operasjonen er kompleks med mange detaljer av vesentlig betydning for resultatet. Kirurgen bør beherske flere ulike anastomoseteknikker. Komplikasjonene er mange og vanskelige å håndtere, og noen reservoarer ender i havari og permanent stomi, ofte etter et lengre sykdomsforløp med flere operasjoner.

\section{Norske forhold}

I perioden 1997-2009 er antall bekkenreservoarer operert ved sykehus i Norge nærmest halvert, fra om lag 100 per år til nå 50, ifølge tall fra Norsk pasientregister (NPR) (1). Over tid er det i alt 29 sykehus som har utført reservoarkirurgi. I 2009 ble 31 av 49 operasjoner utført ved fire universitetssykehus, med 7-9 operasjoner på hvert sted. 18 prosedyrer ble foretatt ved ni andre sykehus. Stikkprøver fra to sykehus tyder på at NPR-tallene er korrekte. Det er få prosedyrekoder, operatørene er erfarne, og feilkoding er neppe en feilkilde. Norske publikasjoner på dette området viser at det er variasjon $i$ havarirate og de funksjonelle resultatene $(1-4)$

\section{Internasjonale forhold}

Tall basert på det engelske bekkenreservoarregisteret $(n=5771)$ viser at mer enn $90 \%$ av teamene hadde gjort færre enn 21 prosedyrer de siste åtte årene (5). $34 \%$ av pasientene ble operert av kirurger som kun hadde operert $0,1-1,3$ prosedyrer per år. $21 \%$ var blitt operert av kirurger med en rate på over 3,6 prosedyrer per år (høyeste volumgruppe). Lavt institusjonsvolum var assosiert med økt havarifrekvens.

Ved St. Mark's Hospital, det mest velrenommerte kolorektalsykehuset i England, fant man en estimert havarirate på $13 \%$ etter ti års reservoarvarighet (6). Fra det engelske registeret er havariraten på landsbasis estimert til $16 \%$ etter ti år, dvs. 1-2\% per år (7). Ved Cleveland Clinic i USA fant man at nødvendig læringsvolum ved maskinstiftede anastomoser ble nådd ved 20 prosedyrer, mens 40 prosedyrer var nød- vendig for håndsydde anastomoser (8). Liten erfaring økte risikoen for havari.

\section{Nødvendig med sentralisering}

Avvikles sporadisk kirurgi, kan kravene til kontinuitet, kirurgisk kvalitetssikring og opplæring innfris. En operasjon i måneden anses som minimum (9).

Argumentene for å redusere sporadisk kirurgi for komplekse prosedyrer er gjerne innlysende - det kreves volum for å beherske selve prosedyren og dens spesielle kliniske betingelser samt at komplikasjonskirurgien må kunne håndteres. Videre kreves det volum for å evaluere og ta i bruk mulige nyvinninger.

I noen situasjoner må den ileoanale anastomosen sys for hånd. Om kirurgteamet ikke behersker alle varianter av inngrepet, kan en operasjon som er teknisk utfordrende ende opp med at pasienten făr en ileostomi istedenfor et reservoar. Reoperasjoner og revisjoner krever mye erfaring med tanke på å kunne bibeholde reservoaret. I situasjoner med reservoarhavari bør teamet kunne tilby konvertering av bekkenreservoaret til kontinent ileostomi eller henvise til slikt.

De toneangivende sentrene har reservoarpoliklinikk. Vår erfaring er at dette bidrar til at livskvaliteten øker for pasienter som trenger hyppige justeringer for å holde reservoarfunksjonen på et akseptabelt nivå. Regelmessige kontroller kan fange opp komplikasjoner i tidlig fase. Slik poliklinikk vil være utenkelig å opprette ved halvparten av norske sykehus.

Noen vil likevel hevde at en kirurg som kan prosedyren, bør kunne gjøre den uavhengig av miljø. Det finnes enkelttilfeller der det kan være riktig ut fra kirurgens kompetanse og pasientens ønske, men for kompetansebygging, opplæring og kontroll er ikke argumentet gyldig. Kritisk diskuterende klinisk virksomhet fundert i teamog kompetansemiljøer er gjeldende standard i dag. Pasienter må ikke unndras dette. Lavvolumrapporter kan vise til gode resultater, men det kan skyldes en strengere eller skjev seleksjon av pasienter (5). Andre pasienter som kunne ha nytte av et bekkenreservoar vil da ikke få det.

Laparoskopisk kirurgi er her en meget krevende prosedyre, både når det gjelder proktektomi og anastomose. Reservoarpasientene er unge, og det kan bli aktuelt i fremtiden å gi tilbud om laparoskopisk behandling til de fleste. Dette vil ytterligere aksentuere argumentene for sentralisering.

Med det pasientgrunnlaget vi har i Norge, er det ikke rimelig at mer enn et par sentre bør utføre bekkenreservoarkirurgi.

\section{Hans H. Wasmuth}

hans.wasmuth@stolav.no

Tom Øresland

Hans H. Wasmuth (f. 1953) er spesialist i gastroenterologisk kirurgi og er overlege ved Avdeling for gastroenterologisk kirurgi, St. Olavs hospital.

Forfatter har fylt ut ICMJE-skjemaet og oppgir ingen interessekonflikter.

Tom Øresland (f. 1949) er professor ved Klinikk for kirurgiske fag, Akershus universitetssykehus, Universitetet i Oslo.

Forfatter har fylt ut ICMJE-skjemaet og oppgir ingen interessekonflikter.

Litteratur

1. Wasmuth $\mathrm{HH}$. Ileal pouches. Doktoravhandling Trondheim: Norges teknisk-naturvitenskapelige universitet, 2012: 10.

2. Stornes T, Skreden K, Sollie AH et al. Bekkenreservoarkirurgi. Tidsskr Nor Legeforen 2010; 130 $1150-2$.

3. Røkke O, Iversen $\mathrm{K}$, Olsen T et al. Long-term followup with evaluation of the surgical and functional results of the ileal pouch reservoir in restorative proctocolectomy for ulcerative colitis. ISRN Gastroenterol 2011; 2011: 625842.

4. Andersson T, Lunde OC, Johnson E et al. Longterm functional outcome and quality of life after restorative proctocolectomy with ileo-anal anasto mosis for colitis. Colorectal Dis 2011; 13: 431-7.

5. Burns EM, Bottle A, Aylin P et al. Volume analysis of outcome following restorative proctocolectomy. Br J Surg 2011; 98: 408-17.

6. Tulchinsky H, Hawley PR, Nicholls J. Long-term failure after restorative proctocolectomy for ulcerative colitis. Ann Surg 2003; 238: 229-34

7. Tekkis PP, Lovegrove RE, Tilney HS et al. Longterm failure and function after restorative proctocolectomy - a multi-centre study of patients from the UK National Ileal Pouch Registry. Colorectal Dis 2010; 12: 433-41.

8. Tekkis PP. Fazio VW, Lavery ICL et al. Evaluation of the learning curve in ileal pouch-anal anastomosis surgery. Ann Surg 2005; 241: 262-8.

9. The European Crohn's and Colitis Organisation. $10^{\text {th }}$ ECCO- Educational Workshop. ECCO - Guidelines 2009. www.ecco-ibd.eu (13.6.2013).

Mottatt 25.2. 2013, første revisjon innsendt 20.4. 2013, godkjent 13.6. 2013. Redaktør Hanne Støre Valeur.

Publisert først på nett. 